\title{
ALÜMİNYUM KÖPÜKLERDE İKİ BOYUTLU ISI TRANSFERİNİN DENEYSEL VE SAYISAL OLARAK İNCELENMESİ
}

\author{
Ahmet Ali SERTKAYA ${ }^{1}$, Burak AKBABA ${ }^{2}$ \\ ${ }^{1}$ Necmettin Erbakan Üniversitesi, Seydişehir Ahmet Cengiz Mühendislik Fakültesi, Makine Mühendisliği \\ Bölümü, 42360 Seydişehir, Konya \\ ${ }^{2}$ Baha Mühendislik Mimarlık Ltd. Şti., Konya \\ alisertkaya@hotmail.com, bu_rak_baba@hotmail.com
}

(Geliş/Received: 29.01.2015; Kabul/Accepted: 23.03.2016)

ÖZET

Bu çalışmada açık hücreli alüminyum köpükler 1sı değiştirici formuna getirilip iki boyutlu 1sı transferi deneysel ve sayısal olarak incelenmiştir. 10, 20 ve 30 PPI (Number of Pores Per Inch) gözenek yoğunluklarına sahip açık hücre alüminyum köpükler sabit 1S1 akısı için 1Sı değiştiricinin kanatlarını oluşturmuştur. Alüminyum köpük üzerinde, X-Y düzleminde özellikle 1sıtıcıya yakın bölgelerde sık olarak yerleştirilen isıl çiftlerle sıcaklıklar ölçülmüştür. Elde edilen sıcaklıklar yardımıyla bütün yüzey üzerindeki sıcaklık dağılımı bulunmuştur. Grafikler, yüzey sıcaklıkları ve giriş sıcaklığı $(\Delta \mathrm{T})$ arasındaki farka dayalı olarak çizilmiştir. Ayrıca her üç 1sı değiştirici için basınç düşüşü bulunmuştur. Sistem için iki boyutlu 1Sı transferi denklemleri sayısal olarak elde edilmişstir. Elde edilen denklemler merkezi fark yöntemi kullanılarak çözülmüştür.

Anahtar Kelimeler: Alüminyum köpük, gözenekli ortam, 1sı transferi

\section{EXPERIMENTAL AND NUMERICAL ANALYSIS OF A TWO DIMENSIONAL HEAT TRANSFER ON OPEN CELL ALUMINUM FOAMS}

\begin{abstract}
In this study, heat transfer was investigated in open cell aluminum foams formed into a heat exchanger experimentally and numerically as two dimensional. The open cell aluminum foams with pore density of 10, 20, 30 PPI were used as the heat exchanger fins formed for a constant heat flow. Temperatures were measured using thermocouples located on several points in the X-Y planes of the aluminum foams especially on areas near the heaters. The temperature distribution for the whole area was obtained from the measured temperatures,. The graphs were plotted based on the difference between the surface temperatures and the inlet temperature $(\Delta T)$. In adition for each of the three heat exchanger pressure drop was found. Two dimensional heat transfer equations for the system were derived in the numerical solution. Then the obtained equations were discretized by using the central difference method and finally solved.
\end{abstract}

Keywords: Aluminum foam, porous media, heat transfer

\section{GİRIŞ (INTRODUCTION)}

Köpük metaller, bünyelerinde \%90’a kadar varan boşluklu yapıya sahiptirler. Hücresel metallerin yapısal kullanım alanları arasında; otomotiv endüstrisi [1], hafif yapı elemanları, çarpışma enerjisi emicisi, hava ve uzay endüstrisi, gemi inşa endüstrisi, yap1 endüstrisi, spor malzemeleri, demiryolu ve inşaat endüstrileri, biyomedikal uygulamalar, işlevsel kullanım alanları arasında ise filtreleme ve ayırma, elektrokimyasal uygulamalar, su aritma, siv1 muhafaza ve iletimi gibi uygulamalar sayılabilir. Köpük metallerin fonksiyonel uygulama alanları olarak 1sı değiştiriciler [2] başta gelmektedir. Yüksek korozyon direnci ve termal iletkenliği gibi özelliklerinden dolayı açık hücreli alüminyum ve bakır bazlı köpük metaller ısı değiştirici ve soğutma sistemlerinde kullanım alanı bulmaktadır. Kapalı 
hücreli köpük metaller ise düşük termal iletkenliklerinden dolayı termal kalkan olarak kullanılırlar. $\mathrm{Bu}$ uygulamaya örnek olarak, yekpare soğutma radyatörleri ve bilgisayar çipleri ile güç elektroniği için mikro elektronik cihazlar verilebilir [1-11]. Metal köpükler üzerine yapılan çalışmalar 1960'lı yıllara kadar dayanmaktadır. Ancak son 15-20 yılda metalik köpüklerin üretimi ve karekterizasyonu üzerine yapılan AR-GE faaliyetleri büyük oranda ivme kazanmıştır [3, 4, 5]. Alüminyum köpükler üzerine hem deneysel hem de sayısal pek çok araştırma yapılmıştır. Bunlardan bazıları kısaca aşağıda belirtilmiştir.

Kim ve arkadaşları bir kanal içerisine yerleştirdikleri farklı gözenek yoğunluğuna sahip alüminyum köpük 1S1 alıcılardan 1S1 transferini zorlanmış taşınım şartlarında incelemişlerdir. Sonuç olarak 1sıl performansın alüminyum köpük malzemelerin gözenek yoğunluğundan fazlasıyla etkilendiğini ifade etmişlerdir. Ayrıca geleneksel paralel plaka tipi kanatçıklarla, köpük malzemelerin ısıl performansını karşılaştırmaları sonucunda köpük malzemelerin \%28 daha iyi ısı transferi sağladığını tespit etmişlerdir [6]. Dukhan ve ark. 10 PPI gözenek yoğunluğunda açık hücreli alüminyum köpükler için bir boyutlu 1s1 transferi analizini yapmışlardır. Boyutsuz eksen $\left(X=\frac{x}{L}\right)$ ve boyutsun sicaklık $\left(\theta=\frac{T_{f m}-T_{\infty}}{T_{b}-T_{\infty}}\right)$ arasında farklı Reynolds sayılarında sicaklık dağılımını incelemişlerdir. Isıtılan taban sıcaklığından uzaklaştıkça sıcaklığın eksponansiyel olarak azaldığını tespit etmişlerdir [7]. Sertkaya ve ark. 10, 20, 30 PPI gözenek yoğunluğuna sahip açık hücreli alüminyum köpüklerde bir boyutlu isı transferini deneysel ve teorik olarak incelemişlerdir. Numuneler bir kanal içine yerleștirilerek bir yüzeyinden 1S1 verilmiş, diğer 3 yüzeyi dış ortama karşı yalıtılarak bir boyutlu ısı transferi akısı sağlanmıştır. Isı verilen alüminyum köpükler üzerine değişik debilerde hava üflenmiştir. Her 3 numunede de alüminyum köpükler üzerine üflenen hava hızı arttıkça ve y ekseni boyunca kanat sıcaklığının azaldığını, x ekseni yönündeki sıcaklık değişiminin ihmal edilebilecek kadar az olduğunu tespit etmişlerdir [8]. Doğan ve Öney elektronik eleman performansına etkilerini araştırmak amacıyla, alüminyum köpük 1sı alıcılarla genişletilmiş 1sı kaynakları bulunan yatay bir kanalda taşınımla gerçekleşen 1sı transferini deneysel olarak incelenmişlerdir. Düzlem yüzeyle 10PPI gözenek yoğunluğuna sahip alüminyum köpükle kaplanan 1s1 alıcıları karşılaştırmışlardır. Düz yüzeyle, 10PPI gözenek yoğunluğuna sahip alüminyum köpük 1s1 alıcıların, geniş 1sı transfer yüzey alanı, yüksek 1sı iletim kapasitesi ve yoğun akış karışımı sağlama özelliğinden dolayı, yüzey sıcaklıklarını \%44-50 oranında düşürdüğü, 1S1 transferini ise \%36-70 oranında artırdığını tespit etmişlerdir [9]. Babcsan ve ark. $30^{\circ} \mathrm{C}$ dan $500^{\circ} \mathrm{C}$ kadar değişik sıcaklıklarda alüminyum köpüklerin termal ve elektrik iletkenliklerini ölçmüşlerdir. Köpük metalin bağıl yoğunluğu azaldıkça elektrik ve termal iletkenliğinin düştüğünü, bağıl yoğunluk arttıkça iletkenliğin arttığını tespit etmişlerdir [10]. Sertkaya ve ark. açık hücreli alüminyum köpük 1S1 değiştiricilerle konvansiyonel kanatlı 1S1 değiştiricilerin 1 ș1 performanslarını deneysel olarak incelemişlerdir. PPI 10, 20 ve 30 özelliklerine sahip, açık hücreli alüminyum köpüklerle, 1,6, 3,2 ve 4,8 mm kanat aralıklarına sahip alüminyum kanatlı konvansiyonel 1S1 değiştiricilerin 1sıl performanslarını karşılaştırmışlardır. Alüminyum köpük ve konvansiyonel 1S1 değiştiriciler için; ReynoldsNusselt sayıları, etkenlik - hız, basınç düşümü - hız ve sürtünme - Reynolds sayısının değişimlerini incelemişlerdir. Alüminyum köpük ve konvansiyonel 1S1 değiştirici sistemlerde soğuk akışkan hızının artmasıyla birlikte etkenliğin azaldığını, basınç kayıplarının arttığını tespit etmişlerdir [11].

Kurtbaş ve Çelik içerisi tamamen köpük malzemeyle kaplanmış yatay bir kanalda zorlanmış ve karışık taşınımla 1sı transferini deneysel olarak incelemişlerdir. Çalışmalarında 10,20 ve 30 PPI gözenek yoğunluğuna sahip metal köpük malzemeler kullanarak 1Sı transfer özelliklerini belirlemişlerdir [12]. Huisseune ve ark. Açık hücreli metal köpük 1sı değiştiricilerle çıplak boru demeti ve geleneksel kanatlı tip 1s1 değiştiricilerin performansını karşılaştırmışlardır. Köpük parametreleri, köpük malzeme ve boyutlarının uygun seçimi yapıldığı takdirde; metal köpük 1sı eşanjörlerinin aynı fan gücünde çıplak boru demetine göre 6 kat daha fazla 1s1 transfer ettiğini bulmuşlardır [13]. Chen ve ark. zorlanmış taşınım şartlarında, iç içe geçmiş, içteki ve dıştaki borunun tamamen alüminyum köpükle doldurulmuş, karşıt akışlı 1S1 değiştiricide 1S1 transferini deneysel ve sayısal olarak incelemişlerdir. Alüminyum köpük kullanmanın özellikle düşük Reynolds sayılarında 1Sı transferini önemli ölçüde iyileştirdiğini tespit etmişlerdir [14]. Schampheleirea ve ark. 1sıtma, havalandırma ve iklimlendirme uygulamaları için açık hücreli 10 PPI alüminyum köpük ve panjur tipi 1sı eşanjörünü karşılaştırmışlardır. Yüksek hızlarda $(2,5-3,1 \mathrm{~m} / \mathrm{s})$ panjur tipinin, düşük hizlarda $(1,1-2,5 \mathrm{~m} / \mathrm{s})$ ise alüminyum köpük 1s1 eşanjörlerinin daha iyi performans gösterdiğini tespit etmişlerdir [15]. Mancin ve ark. poroziteleri 0,905 ve 0,934 arasında 5, 10,20 ve 40 PPI gözenek boyutlarında açık hücreli bakır köpükler üzerinde zorlanmış konveksiyon şartları altında 1sı transferi ve basınç düşüşünü deneysel olarak araştırmışlardır. Test bölgesinde hava hızı 2,5-5 m/s arasında, elektrikli 1sitıcinın 1s1 akıs1 25,0 ve $32,5 \mathrm{~kW} / \mathrm{m}^{2}$ arsında değiştirmişlerdir. Gözenek yoğunluğu arttıkça 1sı transferi ve basınç kaybının exponansiyel olarak arttığını, en fazla 1sı transferi ve basınç düşüşünün 40 PPI' da gerçekleştiğini ifade 
etmişlerdir [16]. Yine Mancin ve ark. 20 PPI sabit gözenek yoğunluklu, 20 ve $40 \mathrm{~mm}$ yüksekliğindeki açık hücreli alüminyum köpüklerin 1sı transfer performansı ve basınç düşüşlerini, $25,32,5$ ve 40 $\mathrm{kW} / \mathrm{m}^{2}$ 1sı akılarında, 2,0 ve $5,0 \mathrm{~m} / \mathrm{s}$ hava hızlarında incelemişlerdir. Deney sonuçlarından yararlanarak 40 mm yüksekliğindeki alüminyum köpüğün 1S1 transferinin $20 \mathrm{~mm}$ yüksekliğindeki numuneye göre daha fazla olduğunu, hız arttıkça 1sı transferinin arttığını Nusselt-Reynolds sayısı grafiklerini çizerek ifade etmişleridir [17]. Schampheleire ve ark. açık hücreli alüminyum köpüklerde doğal taşınımla 1sı transferini deneysel olarak incelenmişlerdir. 10 ve 20 PPI gözenek yoğunluğuna sahip $\% 93$ poroziteye sahip alüminyum köpüklerin yükseklikleri 6 ile $40 \mathrm{~mm}$ arasında değişmiştir. Lehimleme ve epoksi ile yüzeye yapıştırılan numune tabanlarına $55-95^{\circ} \mathrm{C}$ arasında sıcaklık vermişlerdir. Nusselt ve Rayleigh sayıları arasında çizilen grafiklerden lehimleme yöntemi ile yapılan bağlantının epoksi yöntemi ile yapılan bağlantıdan daha iyi 1S1 transferi yaptığını bulmuşlardır [18]. Bu çalışmada; bu alanda daha önce yapılmamış olan 10,20 ve 30 PPI gözenek yoğunluğuna sahip açık hücreli alüminyum köpüklerde iki boyutlu sıcaklık dağılımı hem sayısal hem de deneysel olarak incelenmiştir. Çalışma bu yönüyle literatürdeki diğer çalışmalardan farklılık arz etmektedir. Sayısal çalışma da seçilen kontrol hacmi için iki boyutlu ısı transferi denklemleri geliştirilmiş ve elde edilen denklemler boyutsuz hale getirilerek merkezi fark yöntemi ile ayrıklaştırılmıştır. Deneysel çalışmada ise 3 numune için 0,5-4 m/s hızları arasında $0,5 \mathrm{~m} / \mathrm{s}$ adımlarla iki boyutlu sıcaklık dağılımı elde edilmiştir. Bu hızlardan 1, 2 ve $3 \mathrm{~m} / \mathrm{s}$ hızları için X-Y ekseni boyunca $\Delta \mathrm{T}$ sıcaklık farkına bağlı olarak elde edilen değerlerin 3 boyutlu olarak grafikleri, 0,5-4 m/s hızları içinse hız-basınç düşüşü grafiği çizilmiştir. Elde edilen grafiklerden Y ekseni yönünde sıcaklığın düştüğü, bu düşüşün 1sitıcıya yakın bölgelerde daha yüksek olduğu, X ekseni yönünde ise sıcaklığın arttığı görülmüştür. Birim boydaki basınç düşüşü ise düşük hava hızlarında da az, hava hız arttıkça basınç düşüşünün yükseldiği tespit edilmiştir. İlave olarak gözenek yoğunluğu arttıkça basınç kaybı da arttığı, en fazla basınç düşüşünün 30 PPI gözenek yoğunluğunda olduğu tespit edilmiştir.

\section{DENEYSEL ÇALIŞMA (EXPERIMENTAL STUDY)}

Deneysel çalışmada; bir kanal içerisine yerleştirilmiş açık hücreli alüminyum köpük, taban yüzeyinden bir 1sitıcı vasitası ile 1sitılmış, diğer taraftan da fan yardımı ile üzerine hava üflenerek çapraz akımlı 1sı değiştirici formuna getirilmiştir. Açık hücreli alüminyum köpügün diş ortama bakan yüzeyleri cam ve taş yünü ile izole edilerek iki boyutlu isı geçişi sağlanmıştır. Deneyler 10, 20, 30 PPI gözenek boyutuna sahip açı hücreli (AlSi7Mg) alüminyum köpükler için yapılmıştır [19]. Yapılan literatür taramasında deneysel çalışmalarda 5-40 PPI gözenek yoğunluğundaki alüminyum köpüklerin 1S1 değiştiriciler kanat görevi yapmak için kullanıldığı [69, 11-12, 15-18, 20] daha yüksek gözenek boyutların yüksek basınç düşümü nedeniyle kullanılmadığı, 80 PPI ve üzerinin filtreleme amacıyla kullanıldığı tespit edilmiştir [21]. Deneylerde kullanılan alüminyum köpükler Şekil 1'de verilmiştir. Deney düzeneğinde kullanılan kanalın boyu $1500 \mathrm{~mm}$ kanal kesiti 100x200 mm olmak üzere dikdörtgen şeklindedir. Kanat görevi yapan alüminyum köpüğün 1sıtılması için, özel olarak tasarlanan 100x200 mm boyutlarında $300^{\circ} \mathrm{C}$ sicaklığa kadar çıkabilen esnek 1sıtıcılar kullanılmıştır [22]. Isının homojen dağılımının sağlanması amaciyla esnek 1sitıcı ile alüminyum köpükler arasına $2 \mathrm{~mm}$ kalınlığında aynı ebatta alüminyum levha yerleştirilmiştir. Isıtıcı sıcaklığını sabit tutmak için güç ayarlama devresi kullanılmıştır. Alüminyum köpüğün taban yüzeyi $120^{\circ} \mathrm{C}$ sicaklıkta sabit tutulması için hava hızına göre 1s1 akısı ayarlanmıştır. Isı akısı $0,5 \mathrm{~m} / \mathrm{s}$ hava hızında $50 \mathrm{~W}$ değerinde iken, $4 \mathrm{~m} / \mathrm{s}$ hava hızında $150 \mathrm{~W}$ değerinde olmuştur. Sistemin rejime girmesi düşük hava hızlarında 1 saate kadar çıkarken, yüksek hava

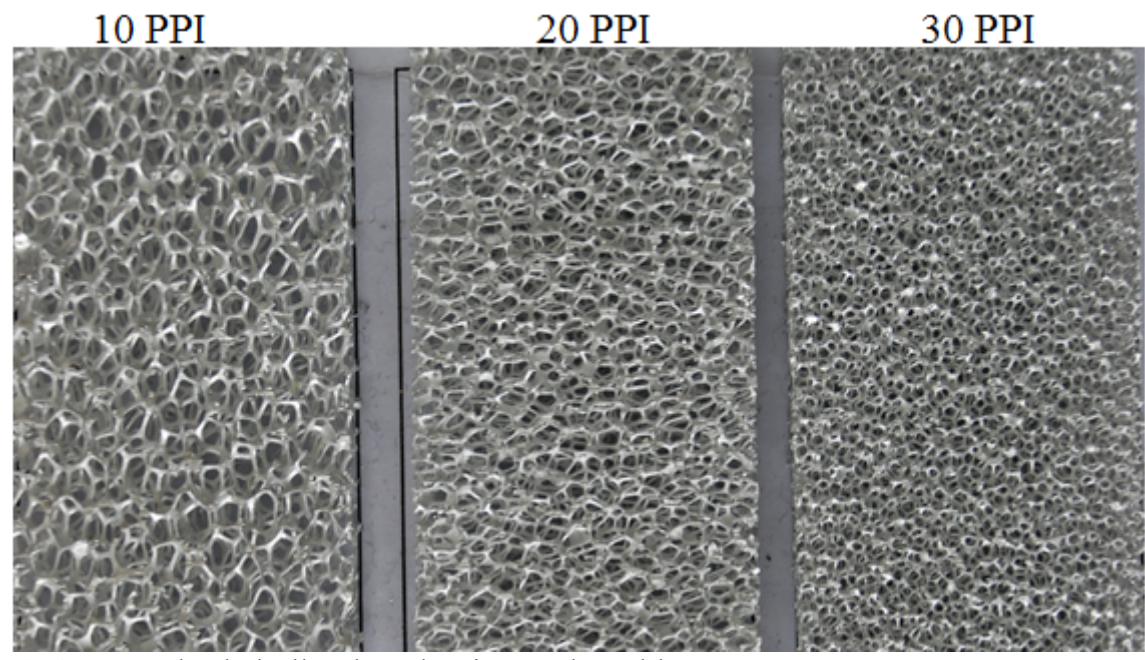

Şekil 1. Deneylerde kullanılan alüminyum köpükler (Aluminum foams used in the experiments) 
Tablo 1. Ölçme aletlerinin karakteristik özellikleri (Characteristics of measuring instruments)

\begin{tabular}{|l|l|c|}
\hline Cihaz & Ölçüm aralı̆̆ & Tolerans \\
\hline Dijital manometre (Kimo-CP304) & -10000 ile $10000 \mathrm{~Pa}$ & $\% \pm 0,5 \mathrm{ile} \pm 10 \mathrm{~Pa}$ \\
\hline Is1l çift (NiCr-Ni T190-1) & -25 ile $400{ }^{\circ} \mathrm{C}$ & $\% \pm 0,8$ \\
\hline Dijital anomometre (DCFM8901 CFM) & 125 ile $4900 \mathrm{fpm}$ & $\% \pm 2$ \\
\hline
\end{tabular}

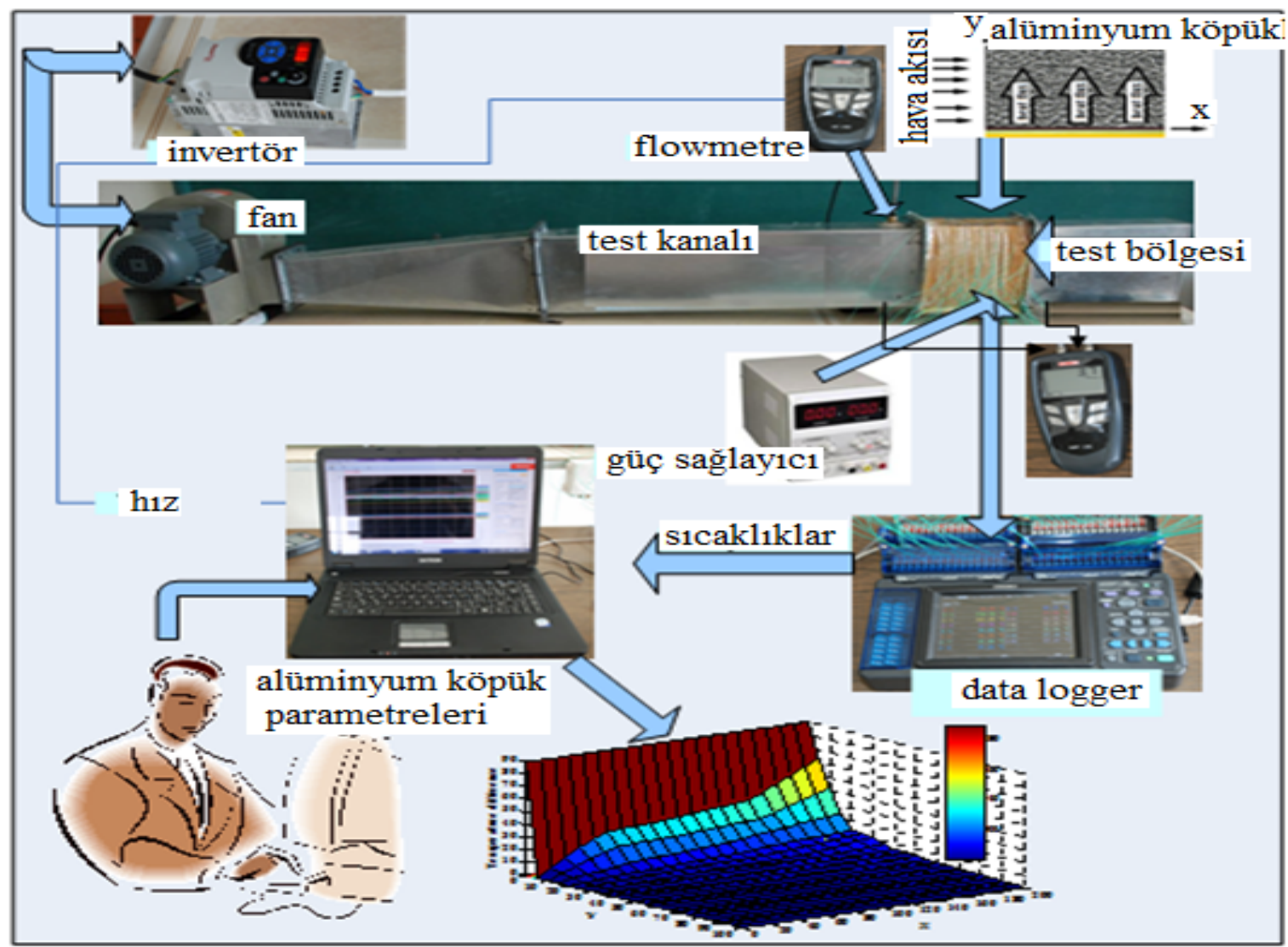

Şekil 2. Deney düzeneği (Experimental setup)

hızlarında 30 dakikaya kadar düşmüştür. Soğutucu akışkan olan havanın debisi kanal girişine yerleştirilen bir fan yardımıyla sağlanmış ve frekans değiştiricisi yardımıyla hızı değiştirilerek debisi ayarlanmıştır. Kanal içi hava hızını ölçmek için dijital anemometre (DCFM8901 CFM), kanal giriş ve çıkışı arasındaki basınç düşüşünü ölçmek için dijital manometre (Kimo-CP 304) kullanılmıştır. Deneylerdeki sıcaklık ölçümleri (NiCr-Ni T190-1) 1sıl çiftler yardımıyla yapılmıştır. Sıcaklıkların alınması ve kaydedilmesi 10 ms gibi kısa bir zaman aralığına kadar ölçüm yapabilen 60 kanallı (HIOKI LR8401) bilgisayar kontrollü veri toplayıcı yardımıyla yapılmıştır. Sistem rejime girdikten sonra her 10 saniyede 1 değer alınarak 5 dakika süreyle ölçüm yapılmış ve bunların aritmetik ortalaması kayda alınmıştır. Deneysel çalışmada kullanılan ölçme aletlerinin karekteristik özellikleri Tablo 1'de, deney düzeneği Şekil 2'de verilmiştir.

\section{TEORİ (THEORY)}

Açık hücreli alüminyum köpükte 2 boyutlu 1Sı transfer modelini incelemek için, kenarları $\mathrm{dx}$, dy ve $\mathrm{dz}$ olan bir kontrol hacmi göz önüne alınmış ve bu kontrol hacmine enerjinin korunumu yasası uygulanmıştır. Alüminyum filamentler arasında iletimle, köpük boşlukları arasında ise taşınımla 1sı transferi gerçekleşmektedir. Bu nedenle, iletim yoluyla olan isı transferi için Fourier yasası ve taşınımla olan 1s1 transferi için Newton'un soğuma yasası, yüzey porozitesi de dikkate alınarak yazılmıştır. İki boyutlu olarak elde edilen ifadeyi çözebilmek için, ifade boyutsuz hale getirilmiş ve daha sonra sınır şartları uygulanmıştır. Ön görülen sınır şartları için ifadeler integral formda yazılarak kontrol hacmi için merkezi fark yöntemi uygulanmıştır. Şekil 3'deki alüminyum köpüğe ait kontrol hacmi için enerji dengesi aşağıdaki gibi yazılmıştır [23].

$\rho c_{p} u \frac{\partial T_{f m}}{\partial x}+q_{x}+q_{y}=q_{x+d x}+q_{y+d y}+q_{c o n v}$

$\mathrm{q}_{\mathrm{x}}=-\mathrm{k}_{\mathrm{s}} \mathrm{dydz}(1-\varepsilon) \frac{\partial T_{f m}}{\partial x}-\varepsilon \mathrm{k}_{\mathrm{f}} \mathrm{dydz} \frac{\partial T_{f m}}{\partial x}$ 


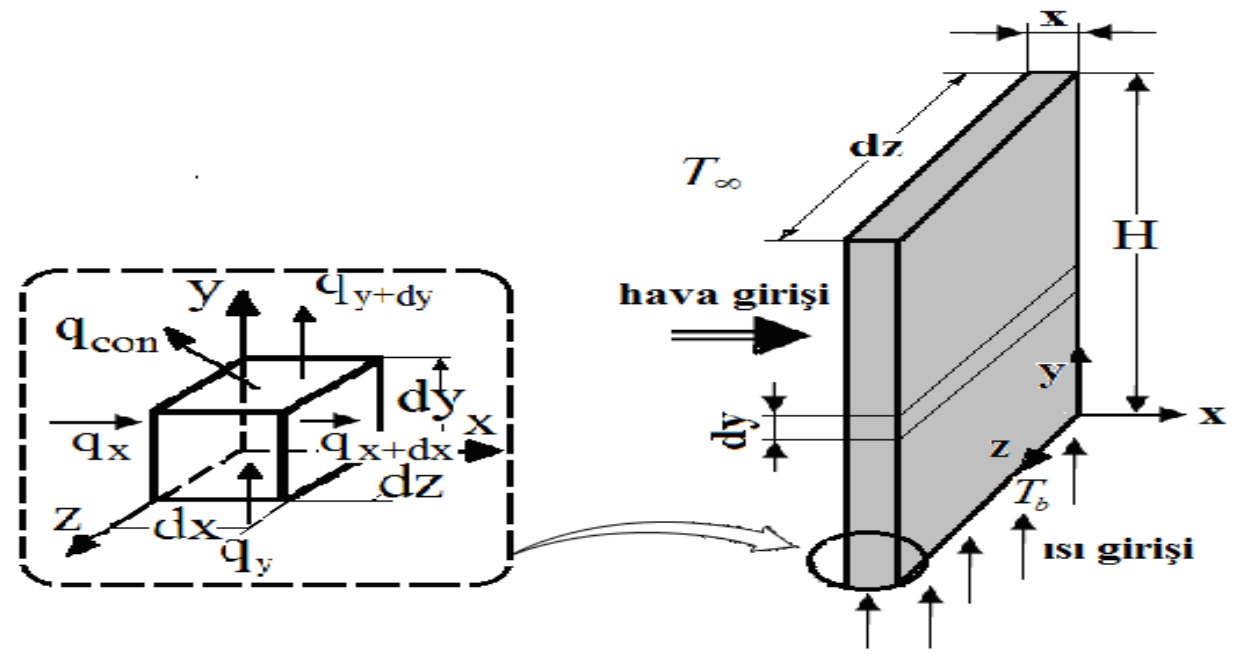

Şekil 3. Kontrol hacmi (Control volume)

$\mathrm{q}_{\mathrm{y}}=-\mathrm{k}_{\mathrm{s}} \mathrm{dxdz}(1-\varepsilon) \frac{\partial T_{f m}}{\partial y}-\mathrm{k}_{\mathrm{f}} \mathrm{dxdz} \varepsilon \frac{\partial T_{f m}}{\partial y}$

$\mathrm{q}_{\mathrm{x}+\mathrm{dx}}=-\mathrm{k}_{\mathrm{s}} \mathrm{dydz}(1-\varepsilon) \frac{\partial T_{f m}}{\partial x}-\mathrm{k}_{\mathrm{s}} \mathrm{dxdydz}(1-\varepsilon) \frac{\partial^{2} T_{f m}}{\partial x^{2}}$

$-\varepsilon \mathrm{k}_{\mathrm{f}} \mathrm{dydz} \frac{\partial T_{f m}}{\partial x}-\varepsilon \mathrm{k}_{\mathrm{f}} \mathrm{dxdydz} \frac{\partial^{2} T_{f m}}{\partial x^{2}}$

$\mathrm{q}_{\mathrm{y}+\mathrm{dy}}=-\mathrm{k}_{\mathrm{s}} \mathrm{dxdz}(1-\varepsilon) \frac{\partial T_{f m}}{\partial y}-\mathrm{k}_{\mathrm{s}} \mathrm{dxdydz}(1-\varepsilon) \frac{\partial^{2} T_{f m}}{\partial y^{2}}$

$-\varepsilon \mathrm{k}_{\mathrm{f}} \mathrm{dxdz} \frac{\partial T_{f m}}{\partial y}-\varepsilon \mathrm{k}_{\mathrm{f}} \mathrm{dxdydz} \frac{\partial^{2} T_{f m}}{\partial y^{2}}$

İfadelerde yer alan katı parçacı̆̆ın ve boşlukların alanı için aşağıdaki ifadeler yazılabilir [24].

$A_{\text {cond }}=A_{c}-A_{p}$

$A_{\text {cond }}=A_{c}(1-\varepsilon)$

$d A_{\text {cond }(x) s}=(1-\varepsilon) d y d z$

$d A_{\text {cond }(x) f}=\varepsilon d y d z$

$d A_{\text {cond }(y) s}=(1-\varepsilon) d x d z$

$d A_{\text {cond }(y) f}=\varepsilon d x d z$

Burada \& yüzey porozitesi olup aşağıdaki gibi verilebilir.
$\varepsilon=1-\left(\frac{V_{s}}{V_{\text {tot }}}\right)[11]$

Kontrol hacminden taşınımla olan 1sı transferi,

$q_{\text {conv. }}=h_{f m} A_{\text {conv. }}\left(T_{f m}-T_{\infty}\right)=h_{f m} \sigma\left(T_{f m}-T_{\infty}\right) d x d y d z$

şeklindedir. Burada $\sigma$ üretici firmalar tarafindan tanımlanan bir özellik olup; birim hacimdeki konvektif yüzey alanını gösterir ve aşağıdaki gibi ifade edilir [24].

$\sigma=\frac{A_{\text {conv }}}{\mathrm{dx} \mathrm{dy} \mathrm{dz}}$

Ayrıca pouseuille akışlarında paralel kenarlı kanallar için akış hızı aşağıdaki gibi alınabilir [25].

$u=\frac{3}{2} u_{m}\left(1-\left(\frac{y}{H / 2}\right)^{2}\right)$

Yukarıdaki ifadeler Denklem 1'de yerine yazılırsa aşağıdaki ifade elde edilir [24].

$$
\begin{aligned}
& \rho c_{p}\left[\frac{3}{2} u_{m}\left(1-\left(\frac{y}{H / 2}\right)^{2}\right) \frac{\partial T}{\partial x}\right]+k_{S}(1-\varepsilon) \frac{\partial^{2} T}{\partial x^{2}}+k_{S}(1-\varepsilon) \frac{\partial^{2} T}{\partial y^{2}} \\
& +k_{f} \frac{\partial^{2} T}{\partial x^{2}}+k f \frac{\partial^{2} T}{\partial y^{2}}-h_{f m} \sigma\left(T_{f m}-T_{\infty}\right)=0
\end{aligned}
$$

$\mathrm{m}_{\mathrm{fm}}^{2}=\frac{h_{f m} \sigma}{k_{S}(1-\varepsilon)+\varepsilon k_{f}}$ 
alınarak Denklem 16 aşağıdaki gibi yazılabilir.

$$
\begin{aligned}
& \nabla^{2} T_{f m}=m_{f m}^{2}\left(T_{f m}-T_{\infty}\right) \\
& -\frac{1}{\alpha_{f m}}\left(3 / 2 u_{m}\left[1-\left(\frac{y}{H / 2}\right)^{2}\right]\right) \frac{\partial T_{f m}}{\partial x}
\end{aligned}
$$

Başlangıç ve sınır koşulları aşağıdaki şeklinde yazılabilir.

$$
\begin{aligned}
& x=0 \text { 'de } T_{f m}=T_{\infty} ; \\
& x=+\infty \text { için } \quad \frac{\partial T_{f m}}{\partial x}=\frac{q_{0}}{\rho u_{m}{ } p^{H}} ; \\
& y=0 \text { 'da } \quad T_{f m}=T_{b} ; \quad y=H \text { için } \quad T_{f m}=T_{\infty}
\end{aligned}
$$

Boyutsuzlaştırma; parametre sayısını azaltmak ve daha az parametre ile işlem yapmak için başvurulan bir matematiksel yöntemdir. İki boyutlu isı transferi analizi için kullanılan boyutsuz parametreler aşağıdaki gibi tanımlanmıştır. [23, 26]

$X=\frac{x}{H P e} ; \quad Y=\frac{y}{H} ; \quad M^{2}=H^{2} m_{f m}^{2}$

$\alpha_{f m}=\frac{k_{f m}}{\rho c_{p}} ; \quad k_{f m}=k_{S}(1-\varepsilon)+k_{f} \varepsilon$

$P e=\frac{u_{m} \rho c_{p} H}{k_{f m}} ; \quad \theta=\frac{T_{f m}-T_{\infty}}{\frac{q_{0} H}{k_{f m}}}$

$\frac{\partial T}{\partial x}=\left(\frac{q_{0}}{k_{f m} P e}\right) \frac{\partial \theta}{\partial X} ; \quad \frac{\partial T}{\partial y}=\left(\frac{q_{0}}{k_{f m}}\right) \frac{\partial \theta}{\partial Y} ;$

$\frac{\partial}{\partial x}=\frac{1}{H P e} \frac{\partial}{\partial X} ; \quad \frac{\partial}{\partial y}=\frac{1}{H} \frac{\partial}{\partial Y} ;$

$\frac{\partial^{2} T}{\partial x^{2}}=\left(\frac{q_{0}}{P e^{2} k_{f m} H}\right) \frac{\partial^{2} \theta}{\partial X^{2}} ; \quad \frac{\partial^{2} T}{\partial y^{2}}=\left(\frac{q_{0}}{k_{f m} H}\right) \frac{\partial^{2} \theta}{\partial Y^{2}} ;$

Boyutsuz parametreler Denklem 16' da yerine yazılırsa Denklem 19 aşağıdaki gibi elde edilir.

$\frac{3}{2}\left(1-4 Y^{2}\right) \frac{\partial \theta}{\partial X}+\frac{1}{P e^{2}} \frac{\partial^{2} \theta}{\partial X^{2}}+\frac{\partial^{2} \theta}{\partial Y^{2}}-M^{2} \theta=0$
Boyutsuz denklem için sınır şartları aşağıdaki gibi yazılabilir.

$$
\begin{aligned}
& x=0 \quad \text { da } \quad X=\frac{x}{H \cdot P e} ; \\
& X=0 \quad d a \quad T_{f m}=T_{\infty} \text { ve } \quad \theta_{f m}=0 \\
& \mathrm{x}=+\infty \quad \text { için } \quad X=\frac{x}{H \cdot P e} ;
\end{aligned}
$$

$X=+\infty$ için $\quad \frac{\partial T_{f m}}{\partial x}=\frac{q_{0}}{\rho u_{m} c_{p} H} ; \quad \frac{\partial \theta_{f m}}{\partial X}=1 ;$

$y=0$ için $\quad Y=\frac{y}{H}$;

$\mathrm{Y}=0 \quad$ için $\quad T_{f m}=T_{b} ; \quad \theta_{f m}=\frac{T_{b}-T_{\infty}}{\frac{q_{0} H}{k_{f m}}} ;$

$y=H$ için $Y=\frac{H}{H} ; \quad \mathrm{Y}=1 \quad$ için $\quad T_{f m}=T_{\infty} ; \quad \theta_{f m}=0$

Diferansiyel denklemlerin sayısal çözümü için ayrıklaştırma gerekir ve ayrıklaştırma için çeşitli metotlar kullanılabilir. Bu çalışmada en çok kullanılan ayrıklaştırma yöntemlerinden merkezi fark yöntemi kullanılmıştır. Şekil 4'de kenarları dx, dy ve dz olan bir kontrol hacmi ve $\theta-X$ 'e göre oluşturulan grid verilmiştir. Kontrol hacmin merkezinin koordinatları $\mathrm{i}, \mathrm{j}$ ve $\mathrm{k}$ olsun.

Şekil 3'de verilen kontrol hacmi için Denklem 17 integral formda aşağıdaki şekilde yazılabilir.

$$
\begin{aligned}
& \int_{j-1}^{j+1} \int_{i-1}^{i+1} \frac{3}{2}\left(1-4 Y^{2}\right) \frac{\partial \theta}{\partial X} \mathrm{dXdY}+\int_{j-1}^{j+1} \int_{i=1}^{i+1} \frac{1}{P e^{2}} \frac{\partial}{\partial X}\left(\frac{\partial \theta}{\partial X}\right) \mathrm{dXdY} \\
& +\int_{i-1}^{i+1} \int_{j-1}^{j+1} \frac{\partial}{\partial Y}\left(\frac{\partial \theta}{\partial Y}\right) \mathrm{dYdX}-\int_{j-1}^{j+1} \int_{i-1}^{i+1} M^{2} \theta \mathrm{dXdY}
\end{aligned}
$$

Birinci ve ikinci terimler kombinasyon formda aşağıdaki gibi yazılabilir.

$$
\frac{\partial}{\partial \theta}\left[\frac{3}{2}\left(1-4 Y^{2}\right) \theta+\frac{1}{P e^{2}} \frac{\partial \theta}{\partial X}\right]=0
$$

$K=\frac{3}{2} P e^{2}\left(1-4 Y^{2}\right)$

alınarak Denklem 20 aşağıdaki gibi elde edilir.

$$
\frac{\partial^{2} \theta}{\partial X^{2}}+K \frac{\partial \theta}{\partial X}=0
$$

$\mathrm{Bu}$ ikinci dereceden sabit katsayılı lineer homojen bir diferansiyel denklemdir. 

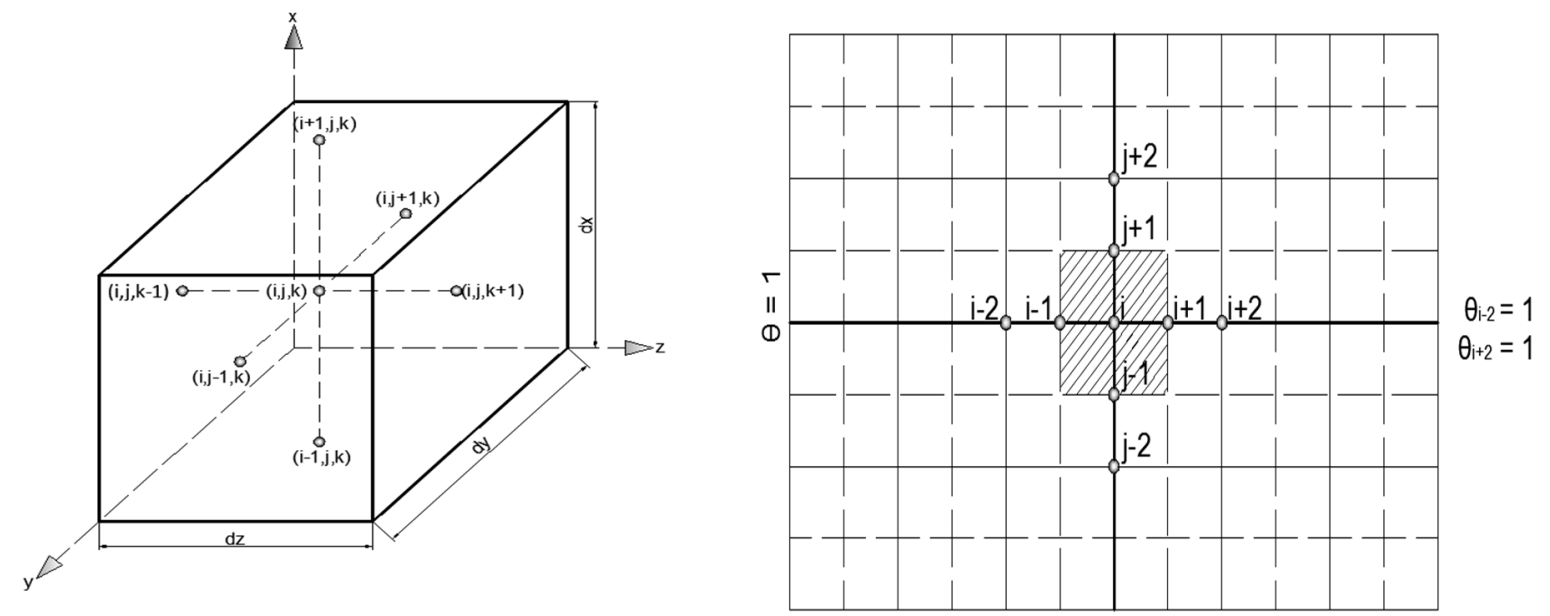

Şekil 4. Kontrol hacmi için merkezi fark ve $\theta-X^{\prime}$ 'e göre oluşturulan grid (Central difference for a control volume and $\theta$ - X formed by the grid)

Bu diferansiyel denklemin çözümü;

$\theta=C_{1} e^{m_{1} X}+C_{2} e^{m_{2} X}=C_{1}+C_{2} e^{-K X}$

şeklindedir. Sınır şartları aşağıdaki gibi yazılabilir [27].

$X=0 \quad$ için $\quad \theta=\theta_{0} \Rightarrow \theta_{0}=C_{1}+C_{2}$

$X=L \quad$ için $\quad \theta=\theta_{L} \Rightarrow \theta_{L}=C_{1}+C_{2} e^{-K L}$

$\frac{\theta-\theta_{0}}{\theta_{L}-\theta_{0}}=\frac{e^{-K X}-1}{e^{-K L}-1}+\frac{e^{-K X}}{e^{-K L}-1} \rightarrow$

$\theta=\theta_{0}+\left(\theta_{L}-\theta_{0}\right)\left(\frac{e^{-K X}-1}{e^{-K L}-1}\right)$

$\frac{d \theta}{d X}=\left[\left(\frac{\theta_{L}-\theta_{0}}{e^{-K L}-1}\right)+\left(e^{-K L}-1\right)\right]=-K+\left(\frac{\theta_{L}-\theta_{0}}{e^{-K L}-1}\right) e^{-K X}$

$J_{X}=\frac{3}{2}\left(1-4 Y^{2}\right)\left[\theta_{0}+\frac{\left(\theta_{L}-\theta_{0}\right) \exp \left(\frac{3}{2}\left(1-4 Y^{2}\right) P e^{2} L\right)}{\exp \left(\frac{3}{2}\left(1-4 Y^{2}\right) P e^{2} L\right)-1}\right]$

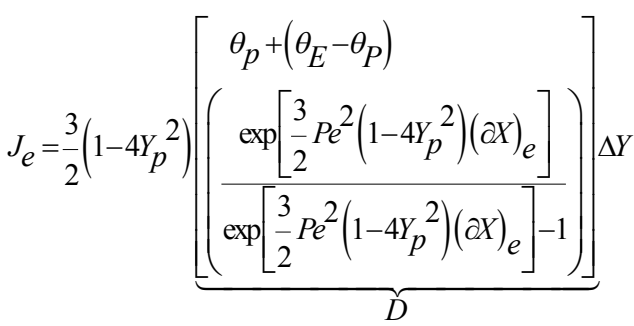

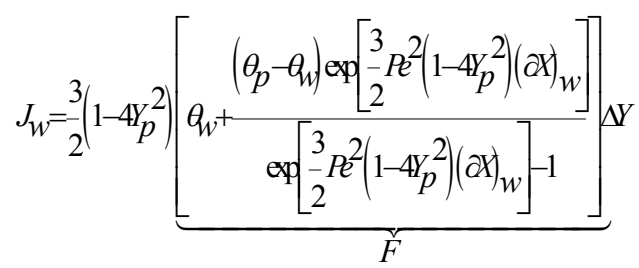

$J_{e}-J_{w}=\frac{3}{2}\left(1-4 Y_{p}^{2}\right)(D-F) \Delta Y$

$\int_{S}^{n} \int_{w}^{e} \frac{\partial}{\partial Y}\left(\frac{\partial \theta}{\partial Y}\right) d X d Y=\left(\left.\frac{\partial \theta}{\partial Y}\right|_{n}-\left.\frac{\partial \theta}{\partial Y}\right|_{S}\right) \Delta X$

$=\left[\frac{\theta_{N}-\theta_{P}}{(\partial Y)_{n}}-\frac{\theta_{P}-\theta_{S}}{(\partial Y)_{S}}\right] \Delta X$

$\int_{S}^{n} \int_{W}^{e} M^{2} \theta d X d Y=\bar{S} \Delta X \Delta Y$ buradan;

$\frac{3}{2}\left(1-4 Y_{p}^{2}\right)\left[\frac{\theta_{p}+\left(\theta_{E}-\theta_{p}\right)}{\exp \left[\frac{3}{2} P e^{2}\left(1-4 Y_{p}^{2}\right)(\delta X)_{e}\right]} \frac{\exp \left[\frac{3}{2} P e^{2}\left(1-4 Y_{p}^{2}\right)(\delta X)_{e}\right]-1}{}\right] \Delta Y$

$-\left[\left(\frac{\exp \left[\frac{3}{2} P e^{2}\left(1-4 Y_{p}^{2}\right)(\delta X)_{w}\right]}{\exp \left[\frac{3}{2} P e^{2}\left(1-4 Y_{p}^{2}\right)(\delta X)_{w}\right]-1}\right)\right] \Delta Y$ 
$a_{P} \theta_{P}=a_{E} \theta_{E}+a_{W} \theta_{W}+a_{N} \theta_{N}+a_{S} \theta_{S}+d$

$a_{P}$ için $a_{P}=a_{E}+a_{W}+a_{N}+a_{S}+c$

$S_{c}=d=0$ ve $c=S_{P} \Delta x=-M^{2} \Delta X$ yazılabilir.

Diğer sabitlerde aşağıdaki gibi yazılabilir,

$a_{E}=\frac{3}{2}\left(1-4 Y_{p}^{2}\right)\left(\frac{\exp \left[\frac{3}{2} P e^{2}\left(1-4 Y_{p}^{2}\right)(\delta X)_{e}\right]}{\exp \left[\frac{3}{2} P e^{2}\left(1-4 Y_{p}^{2}\right)(\delta X)_{e}\right]-1}\right) \Delta Y$

$a_{W}=\frac{3}{2}\left(1-4 Y_{p}^{2}\right)\left(\frac{\exp \left[\frac{3}{2} P e^{2}\left(1-4 Y_{p}^{2}\right)(\delta X)_{w}\right]}{\exp \left[\frac{3}{2} P e^{2}\left(1-4 Y_{p}^{2}\right)(\delta X)_{w}\right]-1}-1\right) \Delta Y$

Denklemleri yeniden düzenlenerek, aşağıdaki sonuçlar elde edilir [27].

$a_{W}=\frac{3}{2}\left(1-4 Y_{p}^{2}\right) \frac{1}{\exp \left[\frac{3}{2} P e^{2}\left(1-4 Y_{p}^{2}\right)(\delta X)_{w}\right]-1} \Delta Y$

$a_{N}=\frac{1}{(\delta Y)_{n}} \Delta X$

$a_{S}=\frac{1}{(\delta Y)_{S}} \Delta X$

Boyutsuz sınır şartları aşağıdaki gibi ifade edilebilir.

$x=+\infty$ için $\frac{\delta \theta}{\delta X}=1 \Rightarrow \frac{\theta_{E}-\theta_{w}}{(\delta X)_{e}+(\delta X)_{w}}=1$

$(\delta X)_{e}=(\delta X)_{w} ; \quad \theta_{E}=\theta_{W}+2(\delta X)_{w}$

Ayrıklaştırma denkleminin yeni sabitleri aşağıdaki formu alır [25].

$a_{E}=0$;

$a_{W}=\frac{3}{2}\left(1-4 Y_{p}^{2}\right)\left(\frac{\exp \left[\frac{3}{2} P e^{2}\left(1-4 Y_{p}^{2}\right)(\delta X)_{w}\right]+1}{\exp \left[\frac{3}{2} P e^{2}\left(1-4 Y_{p}^{2}\right)(\delta X)_{w}\right]-1}\right) \Delta Y$

$a_{N}=\frac{1}{(\delta Y)_{n}} \Delta X$

$a_{S}=\frac{1}{(\delta Y)_{S}} \Delta X$ $d=2(\delta X)_{w} \frac{\exp \left[\frac{3}{2} P e^{2}\left(1-4 Y_{p}^{2}\right)(\delta X)_{w}\right]}{\exp \left[\frac{3}{2} P e^{2}\left(1-4 Y_{p}^{2}\right)(\delta X)_{w}\right]-1} \Delta Y$

Sınır şartları;

$$
\begin{aligned}
& X=0 \text { da } Y=\frac{y}{H} \quad y=0 \quad \text { için } Y=0 \\
& y=0 d a q_{0}=k \frac{\partial T}{\partial y} \Rightarrow \frac{\partial T}{\partial y}=\frac{q_{0}}{k_{f m}} \frac{\partial \theta}{\partial Y} \Rightarrow \\
& \frac{q_{0}}{k_{f m}}=\frac{q_{0}}{k_{f m}} \frac{\partial \theta}{\partial Y} \Rightarrow \quad \frac{\partial \theta}{\partial Y}=1
\end{aligned}
$$

$Y=0$ da $\frac{\partial \theta}{\partial Y}=\left.1 \Rightarrow \frac{\partial \theta}{\partial Y}\right|_{p}=\frac{\theta_{N}-\theta_{S}}{(\delta Y)_{S}+(\delta Y)_{n}}=1 \Rightarrow$

$(\delta Y)_{S}=(\delta Y)_{n} \Rightarrow \theta_{S}=\theta_{N}-2(\delta Y)_{n}$

Denklem 33 yeniden düzenlenerek aşağıdaki gibi yazilabilir.

$\left.\frac{3}{2}\left(1-4 Y_{p}^{2}\right)\left(\begin{array}{c}\exp \left[\frac{3}{2} P e^{2}\left(1-4 Y_{p}^{2}\right)(\delta X)_{e}\right] \\ \exp \left[\frac{3}{2} P e^{2}\left(1-4 Y_{p}^{2}\right)(\delta X)_{e}\right]-1\end{array}\right)-\left(\begin{array}{c}\left.\theta_{p}+\left(\theta_{E}-\theta_{p}\right)+\frac{3}{2} P e^{2}\left(1-4 Y_{p}^{2}\right)(\delta X)_{w}\right] \\ \exp \left[\frac{3}{2} P e^{2}\left(1-4 Y_{p}^{2}\right)(\delta X)_{w}\right]-1\end{array}\right)\right)$

$+\left[2 \frac{\theta_{N}-\theta_{p}}{(\delta Y)_{n}}-2\right] \Delta X-\bar{S} \Delta X \Delta Y=0$

$a_{E}=\frac{3}{2}\left(1-4 Y_{p}^{2}\right)\left(\frac{\exp \left[\frac{3}{2} P e^{2}\left(1-4 Y_{p}^{2}\right)(\delta X)_{e}\right]}{\exp \left[\frac{3}{2} P e^{2}\left(1-4 Y_{p}^{2}\right)(\delta X)_{e}\right]-1}\right) \Delta Y$

$a_{W}=\frac{3}{2}\left(1-4 Y_{p}^{2}\right) \frac{1}{\exp \left[\frac{3}{2} P e^{2}\left(1-4 Y_{p}^{2}\right)(\delta X)_{w}\right]-1} \Delta Y$

$a_{N}=\frac{2 \Delta X}{(\delta Y)_{n}}$

$a_{S}=0$

$d=-2 \Delta X$

$c=-M^{2} \Delta X \Delta Y$

şeklinde yazılabilir. 


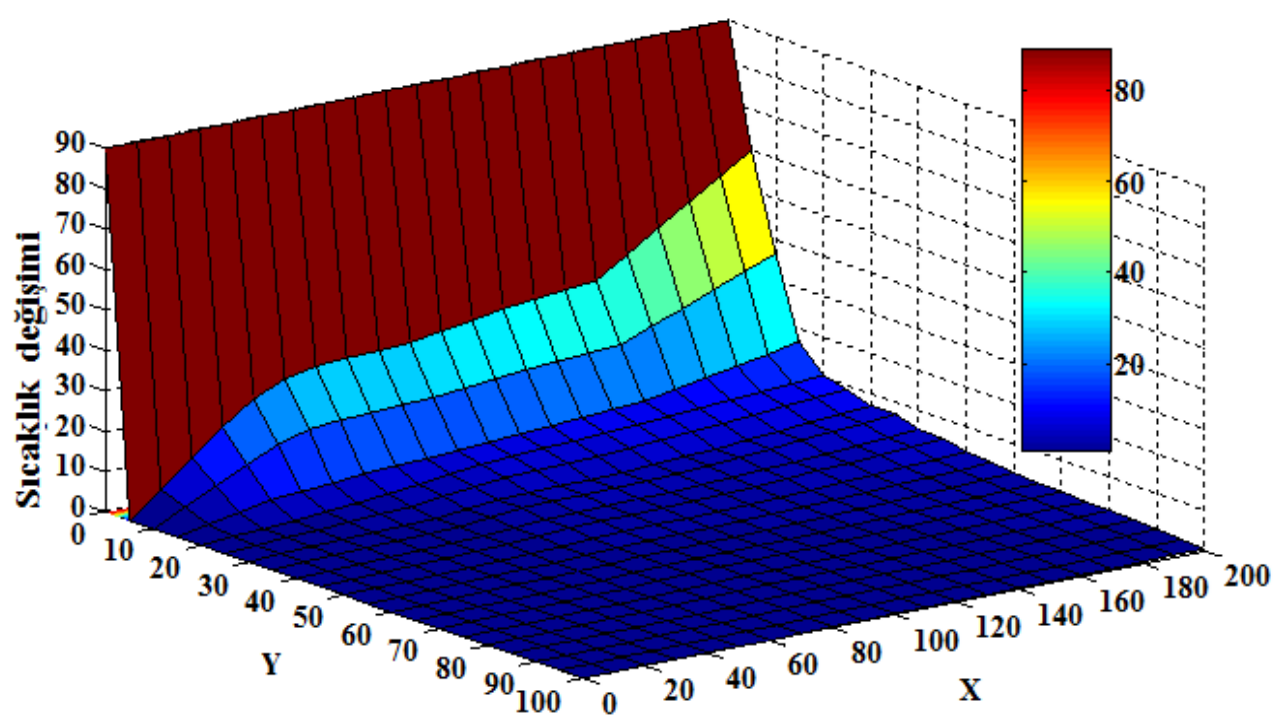

Şekil 5. $10 \mathrm{PPI}$ için $\mathrm{u}=1 \mathrm{~m} / \mathrm{sn}$ hızda $\mathrm{X}-\mathrm{Y}$ ekseni boyunca $\Delta \mathrm{T}$ sıcaklık değişimi (Variation of $\Delta \mathrm{T}$ along $\mathrm{X}-\mathrm{Y}$ axis for $10 \mathrm{PPI}$ foam at a speed of $u=1 \mathrm{~m} / \mathrm{s}$ )

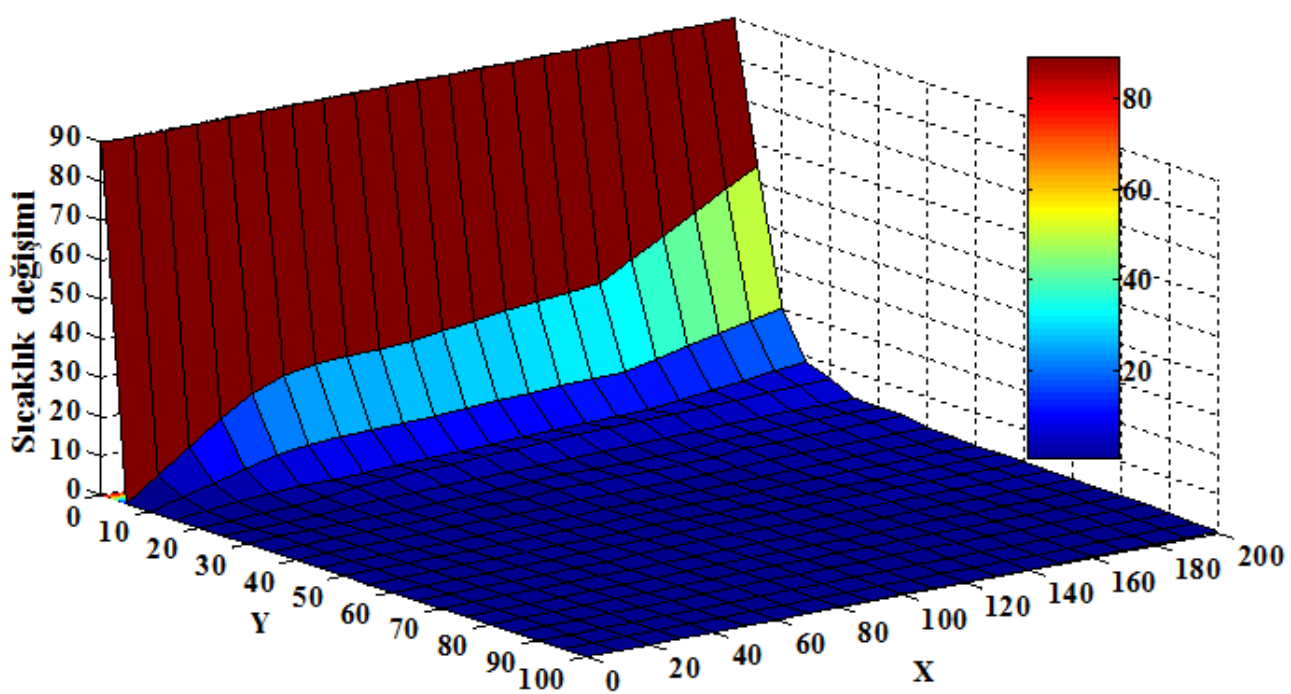

Şekil 6. $10 \mathrm{PPI}$ için $\mathrm{u}=2 \mathrm{~m} / \mathrm{sn}$ hızda $\mathrm{X}-\mathrm{Y}$ ekseni boyunca $\Delta \mathrm{T}$ sıcaklık değişimi (Variation of $\Delta \mathrm{T}$ along $\mathrm{X}-\mathrm{Y}$ axis for $10 \mathrm{PPI}$ foam at a speed of $u=2 \mathrm{~m} / \mathrm{s}$ )

\section{SONUÇLAR VE TARTIŞMA (RESULTS AND DISCUSSION)}

Bu çalışmada açık hücreli 10,20 ve 30 PPI gözenek yoğunluğundaki alüminyum köpük için iki boyutlu 1sı transferi hem deneysel hem de sayısal olarak incelenmiştir. Deneysel çalışmada numuneler için 0,5$4 \mathrm{~m} / \mathrm{s}$ hızları arasında $0,5 \mathrm{~m} / \mathrm{s}$ adımlarla iki boyutlu sıcaklık dağılımı elde edilmiştir. Bunlardan 1, 2 ve 3 $\mathrm{m} / \mathrm{s}$ kanal içi hava hızlarında X-Y düzleminde yüzey sıcaklıkları ölçülerek giriş sıcaklığına göre farkı bulunmuştur [28].

$$
\Delta T=T_{b}-T_{\infty}
$$

0,5-4 m/s hızları içinse hava hızına bağlı olarak basınç düşüşü grafikleri çizilmiştir. Deneysel sonuçlar için elde edilen X-Y eksenlerine bağlı sıcaklık değişim şekilleri aşağıda sunulmuştur.

Şekil 5, 6 ve 7'de 10 PPI gözenek yoğunluğuna sahip alüminyum köpükler için 1,2 ve $3 \mathrm{~m} / \mathrm{s}$ hızlarda X-Y ekseni boyunca $\Delta \mathrm{T}$ sıcaklık değişimi verilmiştir. Grafikler incelendiği zaman $\mathrm{Y}$ ekseni boyunca taban sıcaklığına oranla sıcaklığın düştüğü, $\mathrm{X}$ ekseni yönünde hareket edildiğinde akışkan giriş sıcaklığına oranla sıcaklığın yükseldiği her 3 hızda da görülmüştür. Sicaklık düşüşünün en fazla olduğu hız $3 \mathrm{~m} / \mathrm{s}$ en yavaş olduğu hız $1 \mathrm{~m} / \mathrm{s}$ olarak tespit edilmiştir. 


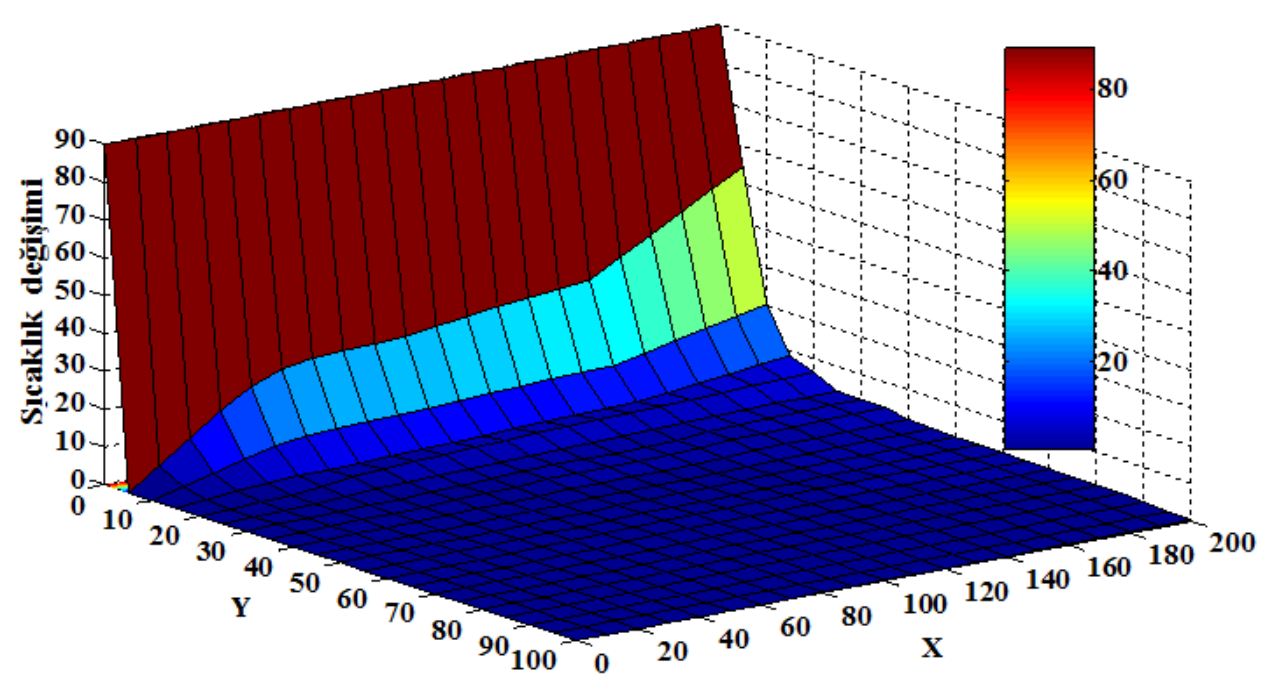

Şekil 7. 10 PPI için $\mathrm{u}=3 \mathrm{~m} / \mathrm{sn}$ hızda $\mathrm{X}-\mathrm{Y}$ ekseni boyunca $\Delta \mathrm{T}$ sıcaklık değișimi (Variation of $\Delta \mathrm{T}$ along $\mathrm{X}$-Y axis for $10 \mathrm{PPI}$ foam at a speed of $u=3 \mathrm{~m} / \mathrm{s}$ )

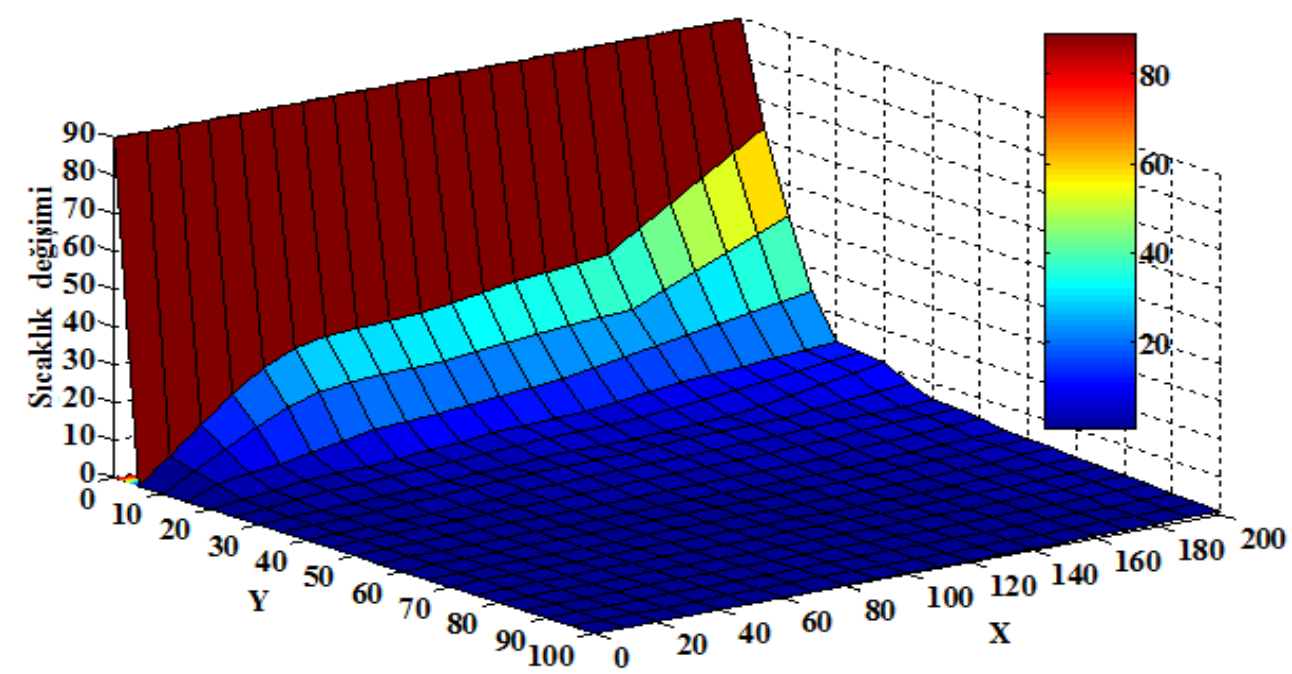

Şekil 8. $20 \mathrm{PPI}$ için $\mathrm{u}=1 \mathrm{~m} / \mathrm{sn}$ hızda $\mathrm{X}-\mathrm{Y}$ ekseni boyunca $\Delta \mathrm{T}$ sıcaklık değişimi (Variation of $\Delta \mathrm{T}$ along $\mathrm{X}-\mathrm{Y}$ axis for $20 \mathrm{PPI}$ foam at a speed of $u=1 \mathrm{~m} / \mathrm{s}$ )

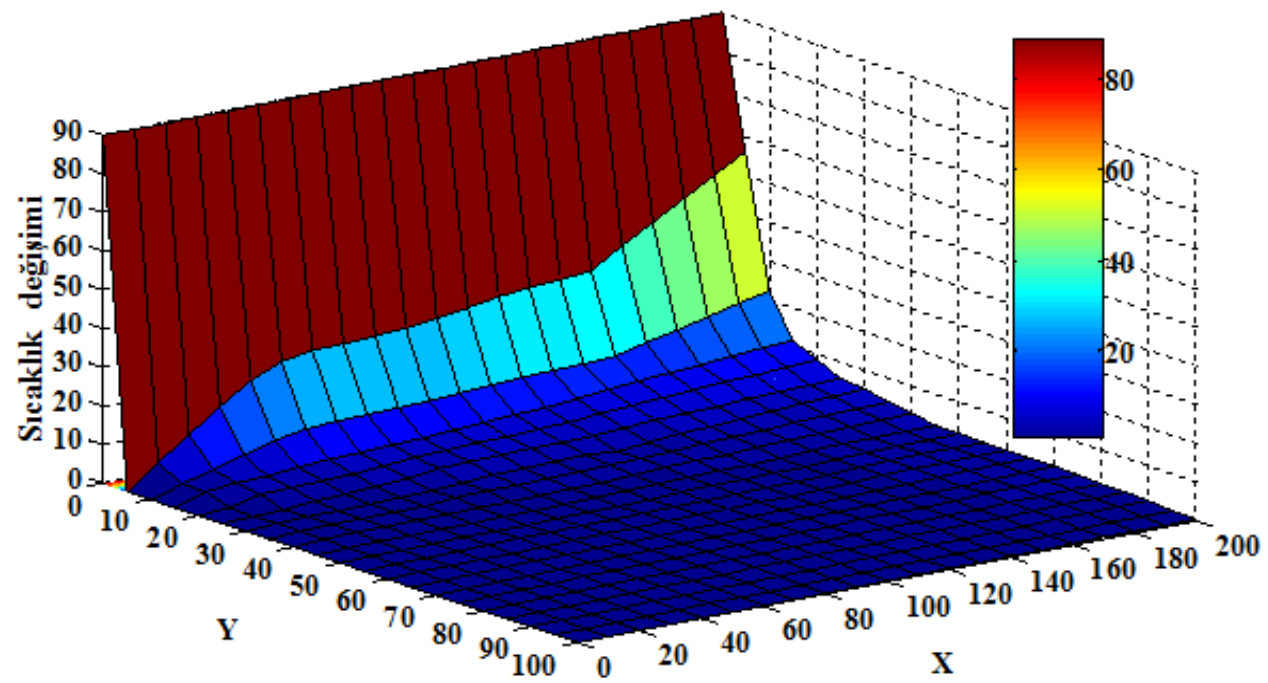

Şekil 9. 20 PPI için $u=2 \mathrm{~m} / \mathrm{sn}$ hızda $\mathrm{X}-\mathrm{Y}$ ekseni boyunca $\Delta \mathrm{T}$ sıcaklık değişimi (Variation of $\Delta \mathrm{T}$ along $\mathrm{X}$-Y axis for $20 \mathrm{PPI}$ foam at a speed of $u=2 \mathrm{~m} / \mathrm{s}$ ) 


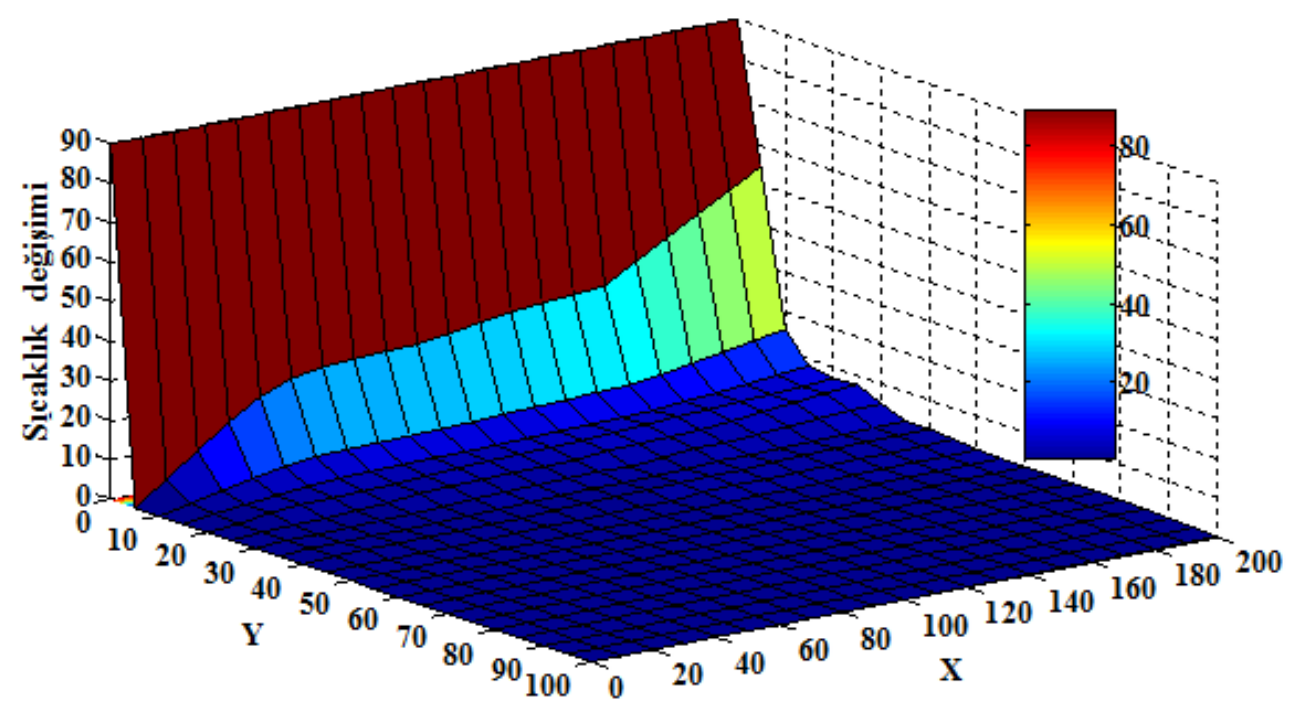

Şekil 10. 20 PPI için $u=3 \mathrm{~m} / \mathrm{sn}$ hızda $\mathrm{X}-\mathrm{Y}$ ekseni boyunca $\Delta \mathrm{T}$ sıcaklık değişimi (Variation of $\Delta \mathrm{T}$ along $\mathrm{X}-\mathrm{Y}$ axis for 20 PPI foam at a speed of $u=3 \mathrm{~m} / \mathrm{s}$ )

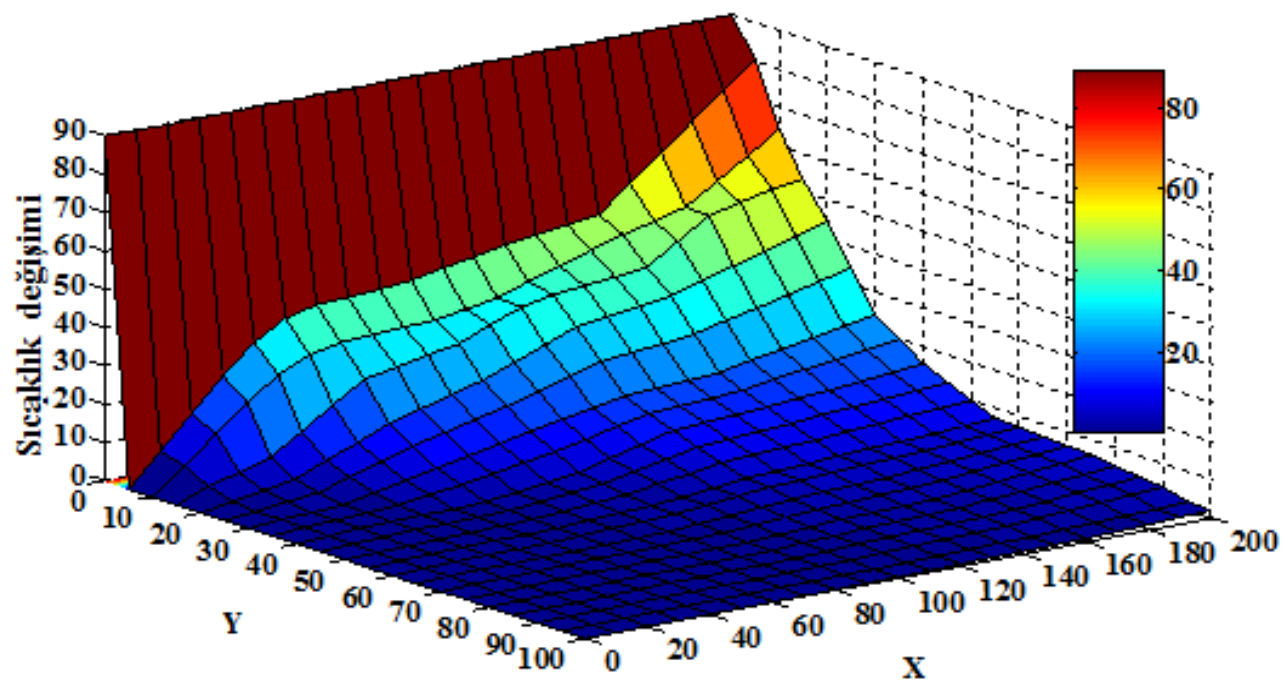

Şekil 11. $30 \mathrm{PPI}$ için $\mathrm{u}=1 \mathrm{~m} / \mathrm{sn}$ hızda $\mathrm{X}-\mathrm{Y}$ ekseni boyunca $\Delta \mathrm{T}$ sıcaklık değişimi (Variation of $\Delta \mathrm{T}$ along $\mathrm{X}-\mathrm{Y}$ axis for 30 PPI foam at a speed of $u=1 \mathrm{~m} / \mathrm{s}$ )

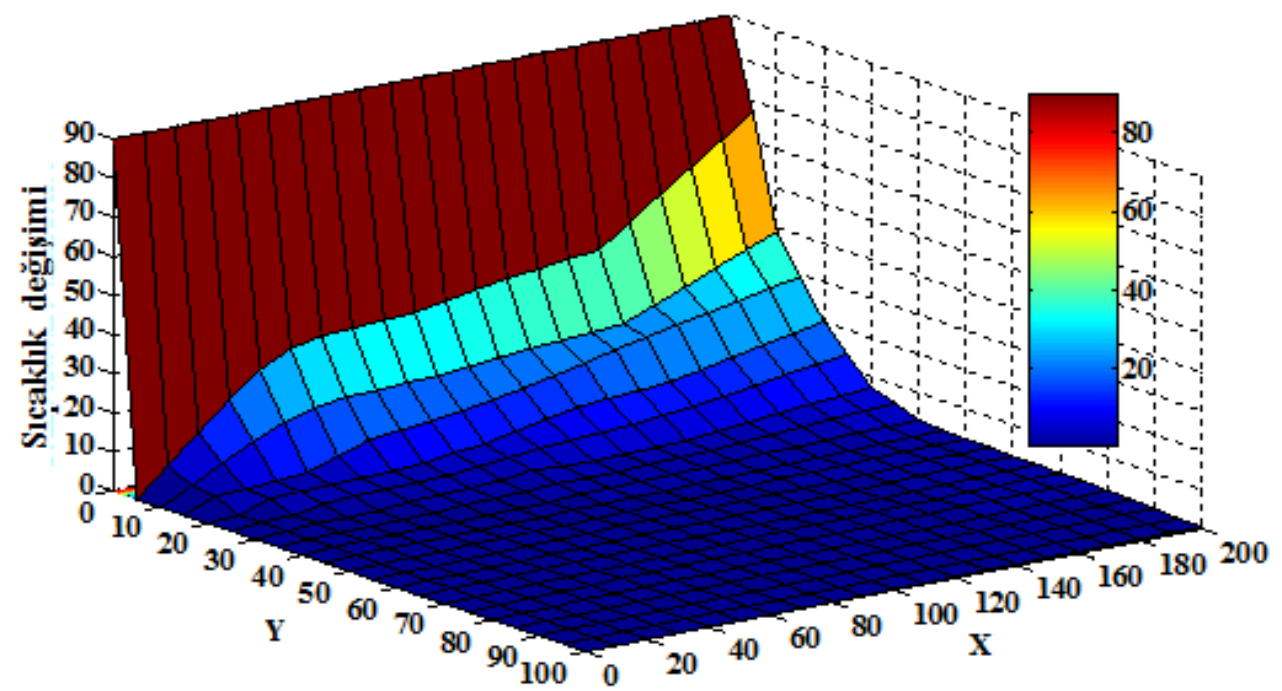

Şekil 12. 30 PPI için $u=2 \mathrm{~m} / \mathrm{sn}$ hızda $\mathrm{X}-\mathrm{Y}$ ekseni boyunca $\Delta \mathrm{T}$ sıcaklık değişimi (Variation of $\Delta \mathrm{T}$ along $\mathrm{X}-\mathrm{Y}$ axis for 30 PPI foam at a speed of $u=2 \mathrm{~m} / \mathrm{s}$ ) 


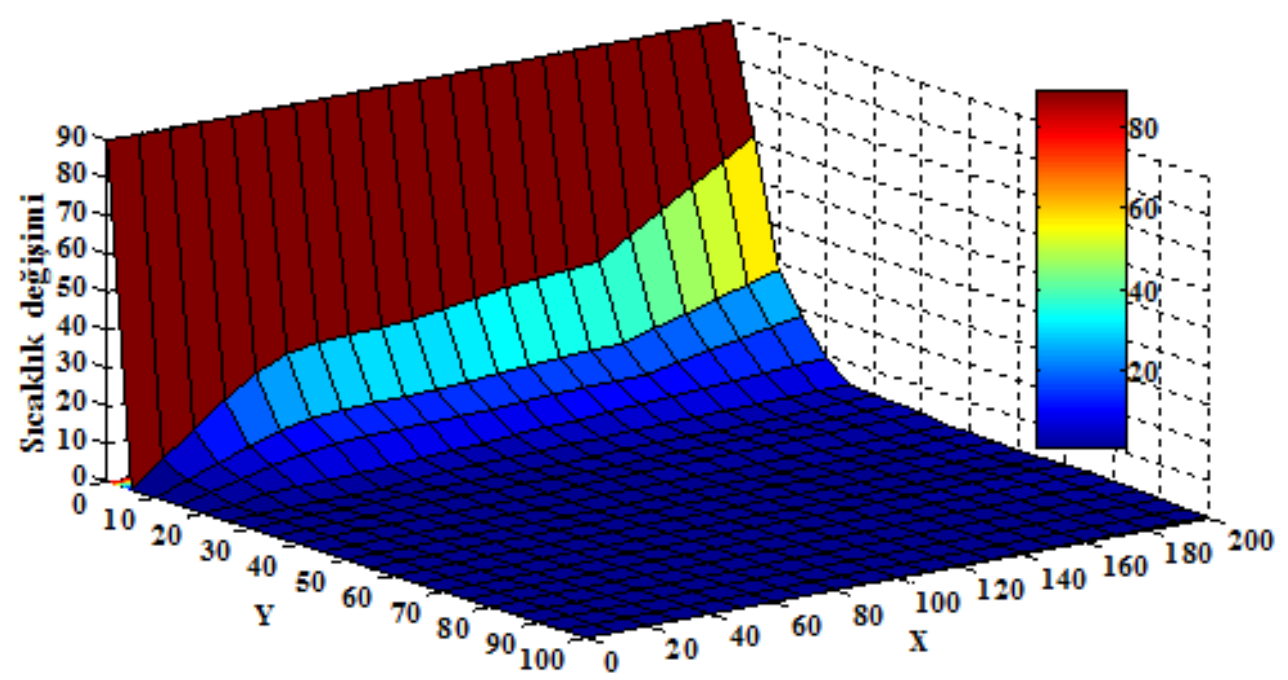

Şekil 13. 30 PPI için $\mathrm{u}=3 \mathrm{~m} / \mathrm{sn}$ hızda $\mathrm{X}-\mathrm{Y}$ ekseni boyunca $\Delta \mathrm{T}$ sıcaklık değişimi (Variation of $\Delta \mathrm{T}$ along $\mathrm{X}-\mathrm{Y}$ axis for 30 PPI foam at a speed of $u=3 \mathrm{~m} / \mathrm{s}$ )

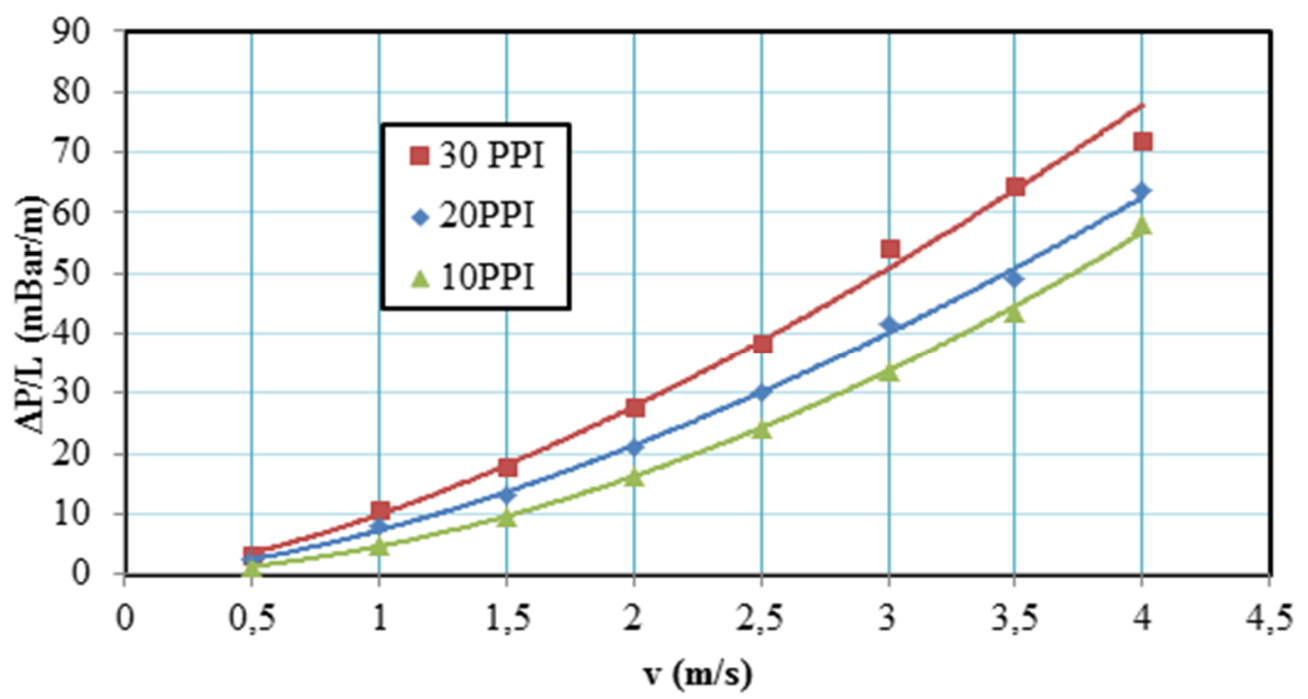

Şekil 14. 10, 20 ve 30 PPI için basınç düşüşü - hız değişimi (Pressure drop - speed change for 10, 20 and 30 PPI)

Şekil 8,9 ve 10’da 20 PPI gözenek yoğunluğu için 1,2 ve $3 \mathrm{~m} / \mathrm{s}$ hızlar için X-Y ekseni boyunca $\Delta \mathrm{T}$ sicaklık değişimi verilmiştir. Burada da grafikler incelendiği zaman $\mathrm{Y}$ ekseni yönünde taban sıcaklığına oranla sıcaklığın düştüğü, $\mathrm{X}$ ekseni boyunca akışkan giriş sıcaklığına oranla sıcaklığın yükseldiği her 3 hızda da görülmüştür. Yine sıcaklık düşüşünün en fazla olduğu hız $3 \mathrm{~m} / \mathrm{s}$, en yavaş olduğu hiz $1 \mathrm{~m} / \mathrm{s}$ olarak tespit edilmiştir. Ancak buradaki Y ekseni boyunca sicaklık düşüşleri 10 PPI gözenek yoğunluğuna sahip alüminyum köpüklere oranla daha az düşüş göstermektedir. X ekseni boyunca sıcaklık artışı yine 10 PPI daki değerlere göre daha yüksektir. Şekil 11,12 ve 13'de 30 PPI gözenek yoğunluğu için 1,2 ve $3 \mathrm{~m} / \mathrm{s}$ hızlar için X-Y ekseni boyunca $\Delta \mathrm{T}$ sicaklık değişimi verilmiştir. 30 PPI gözenek yoğunluğu için Y ekseni boyunca sicaklık düşüşleri 10 ve 20 PPI gözenek yoğunluğuna sahip alüminyum köpüklere oranla daha az olduğu, X ekseni boyunca sıcaklık artışı da 10 ve 20 PPI daki değerlere göre daha yüksek olduğu belirlenmiştir. $\mathrm{Bu}$ sonuç gözenek yoğunluğu arttıkça soğuk akışkanın sıcak akışkanla daha fazla temasta olduğunu ve filamentlerin daha fazla 1Sı depoladıklarını göstermektedir. Şekil 14'de 10, 20, 30 PPI için birim boy başına basınç düşüşü ve hava hızı arasındaki değişim verilmiştir. Düşük hızlarda basınç düşüşü düşük, hız arttıkça basınç düşüşü yükselmektedir. Bu artış lineer olmayıp yüksek hızlarda daha fazladır. Yine grafiklerden görüldüğü gibi gözenek yoğunluğu arttıkça basınç kaybı da artmaktadır. En fazla basınç düşüşü 30 PPI gözenek yoğunluğunda görülmüştür. Gözenek yoğunluğunun artmasıyla birlikte, akışta türbülans ve sürtünme artmakta, bu etkenler basınç düşüşünü yükseltmektedir.

\section{SONUÇLAR (CONCLUSIONS)}

Bu çalışmada 10, 20 ve 30 PPI gözenek yoğunluğuna sahip açık hücreli alüminyum köpüklerde iki boyutlu sıcaklık dağılımı hem sayısal hem de deneysel olarak 
incelenmiştir. Sayısal çalışma da sistem için iki boyutlu isı transferi denklemleri geliştirilmiştir. Seçilen kontrol hacmi için Fourier 1sı iletim yasası ve Newton'un soğuma yasası, yüzey porozitesi de dikkate alınarak yazılmıştır. Elde edilen denklem boyutsuz hale getirilmiştir. Boyutsuz denklemler merkezi fark yöntemi ile ayrıklaştırılmıştır. Deneysel çalışmada ise 3 farklı gözenek yoğunluğu için 1, 2 ve $3 \mathrm{~m} / \mathrm{s}$ hızları için X-Y ekseni boyunca $\Delta \mathrm{T}$ sıcaklık farkına bağlı olarak elde edilen değerlerin 3 boyutlu grafikleri çizilmiş, 0,5-4 m/s hızları içinse hava hızıbasınç düşüşü grafiği elde edilmiştir. Elde edilen grafiklerden Y ekseni yönünde sıcaklığın düştüğü, bu düşüşün 1sıtıcıya yakın bölgelerde daha yüksek olduğu görülmüştür. X ekseni yönünde ise akışkanın hareketi yönünde enerji kazanması nedeniyle arttığı, ısıtıcıya yakın yerlerde sıcaklık artışının daha fazla olduğu görülmüştür. Yüksek gözenek yoğunluklarında sıcaklık düşüşünün daha yavaş olduğu, düşük hızlarda sıcaklık düşüşünün yavaş olduğu, hızın artması ile birlikte her iki eksen yönünde de sıcaklık düşüşünün hızlı olduğu deneysel olarak belirlenmiştir (Şekil 5-13). Bu durum bu tür 1S1 değiştiricilerde zorlanmış taşınımla olan 1S1 transferinin iletim ile olan 1s1 transferinden daha yüksek olduğu kanaatini oluşturmuştur. Düşük hızlarda basınç düşüşü düşük, hız arttıkça basınç düşüşü yükselmektedir. $\mathrm{Bu}$ artış lineer olmayıp yüksek hızlarda daha fazladır. Yine gözenek yoğunluğu arttıkça (Şekil 14) basınç kaybının da arttığ1 tespit edilmiştir. En fazla basınç düşüşü 30 PPI gözenek yoğunluğunda görülmüştür. Artan gözenek yoğunluğu ile birlikte akışta türbülans ve sürtünme artması, basınç düşüşünü yükseltmiştir.

\section{TEŞEKKÜR (ACKNOWLEDGEMENT)}

Bu araștırma, Selçuk Üniversitesi Bilimsel Araştırma Projeleri Koordinatörlüğü tarafindan desteklemiştir. Proje No: 09401075

\section{SEMBOLLER VE KISALTMALAR (SYMBOLS AND ABBREVIATIONS)}

$\boldsymbol{A} \quad$ Yüzey alanı, $\mathrm{m}^{2}$

a Ayrıklaştırılmış denklemlerde katsayı

b Ayrıklaştırılmış denklemlerde kaynak terimi

$c_{p} \quad$ Özgül 1sı, $\mathrm{W} \mathrm{kg}^{-1} \mathrm{C}^{-1}$

$\boldsymbol{d x}, \boldsymbol{d y}, \boldsymbol{d z}$ Kontrol hacminin yüksekliği, derinliği ve genişliği, m

$\boldsymbol{h} \quad$ Taşımımla ısı transferi katsayısı, $\mathrm{W} \mathrm{m}{ }^{-2}{ }^{\circ} \mathrm{C}^{-1}$

$\boldsymbol{H} \quad$ Numune yüksekliği, $m$

$\boldsymbol{k} \quad$ Metal köpük için iletkenlik katsayısı, W m ${ }^{-}$ ${ }^{10} \mathrm{C}^{-1}$

$\boldsymbol{L} \quad$ Metal köpük uzunluğu, Deney düzeneği boyu, $\mathrm{m}$

$\boldsymbol{m} \quad$ Metal köpük parametresi, $\mathrm{m}^{-2}$

$\boldsymbol{M} \quad$ Boyutsuz metal köpük parametresi

$\mathrm{Nu} \quad$ Nusselt sayısı
PPI Metal köpüğün bir inch uzunluğundaki gözenek sayıs1

Pe Peclet sayisı

$q \quad$ Isı transferi miktarı, W

$\boldsymbol{R e} \quad$ Reynolds sayisi

$\boldsymbol{T}$ Sicaklığı, K

$\boldsymbol{t} \quad$ Kalınlık, m

$\boldsymbol{u} \quad$ Hava hizı, $\mathrm{ms}^{-1}$

$\boldsymbol{V} \quad$ Hacmi, $\mathrm{m}^{3}$

$\boldsymbol{X}, \boldsymbol{Y}, \boldsymbol{Z} \quad$ Boyutsuz eksenler

Yunanca Semboller (Greek Symbols)

$\begin{array}{ll}\Delta P & \text { Basınç farkı, Pa } \\ \alpha & \text { Akışkanın ısıl yayılım katsayısı, } \mathrm{m}^{2} \mathrm{~s}^{-1} \\ \varepsilon & \text { Yüzey porozitesi } \\ \theta & \text { Boyutsuz ısı transferi katsayısı } \\ \mu & \text { Dinamik viskozite, Pas } \\ \nu & \text { Akışkanın kinematik viskozitesi, } \mathrm{m}^{2} \mathrm{~s}^{-1} \\ \rho & \text { Yoğunluk, kgm } \\ \sigma & \text { Birim hacimdeki yüzey alanı, } \mathrm{m}^{2} \mathrm{~m}^{-3}\end{array}$

Alt İndis ve Kısaltmalar (Subscripts and Abbreviations)

b Alt, taban

c Akışa dik, soğuk

cond İletim

conv Taşınım

$\boldsymbol{E}, \boldsymbol{e} \quad$ Doğu

f Akışkan

fm Metal köpük

$\boldsymbol{h} \quad$ Sicak

$\boldsymbol{N}, \boldsymbol{n}$ Kuzey

p Boşluk

$\boldsymbol{S}, \boldsymbol{s} \quad$ Kat1, güney

$\boldsymbol{t}$ Üst

tot Toplam

$\boldsymbol{W}, \boldsymbol{w} \quad$ Bat, duvar

$\infty \quad$ Ortam

\section{KAYNAKLAR (REFERENCES)}

1. Banhart, J., Aluminium Foams for lighter vehicles, International Journal of Vehicle Design, Cilt 37, No 2-3, 114-125, 2005.

2. Boomsma, K., Poulikakos, D., Zwick, F., "Metal foams as compact high performance heat exchangers", Mechanics of Materials, Cilt 35, 1161-1176, 2003.

3. Tamayol, J., Yeom, M., Akbari, M., Bahrami, L., "Reynolds number flows across ordered arrays of micro-cylinders embedded in a rectangular micro/ minichannel", International Journal of Heat and Mass Transfer, Cilt 58, 420-426, 2013.

4. Nazari, M., Ashouri, M., Kayhani, M. Tamayol, H.A., "Experimental study of convective heat transfer of a nanofluid through a pipe filled with metal foam", International Journal of Thermal Sciences, Cilt 88, 33-39, 2015. 
5. Mancin, S., Zilio, C., Diani, A., Rossetto, L., "Experimental air heat transfer and pressure drop through copper foams", Experimental Thermal Fluid Science, Cilt 36, 224-232, 2012.

6. Kim, S.Y., Paek J.W., Kang B.H., "Thermal Performance of aluminum-foam heat sinks by forced air cooling", IEEE Transactions on components and packaging technologies, Cilt 6, 262-267, 2003.

7. Dukhan, N., Romes, P.D.Q., Ruiz, E.C., Reyes, M.V. Scott E.P., "One dimensional heat transfer analysis in open-cell 10-PPI metal foam", International Journal of Heat and Mass Transfer, Cilt 48, 5112-5120, 2005.

8. Sertkaya, A.A., Ateş, A., Altınışık, K., Dinçer, K., "Experimental and Numerical Analysis of one Dimensional Heat Transfer on Open Cell Aluminum Foams", Gazi University Journal of Science, Cilt 28, No 1, 149-159, 2015.

9. Doğan, A., Öney, B., “Alüminyum köpük 1s1 alıcılardan taşınımla 1sı transferinin deneysel olarak incelenmesi", Journal of the Faculty of Engineering and Architecture of Gazi University, Cilt 29, No 1, 71-78, 2014.

10. Babcsan, N., Meszaros, I. Hegman, N., "Thermal and Electrical Conductivity Measurements on Aluminum Foams", Materials Science \& Engineering Technology, Werkstofftech, Cilt 34, 391-394, 2003.

11. Sertkaya, A.A., Altınışık, K., Dinçer, K., "Experimental investigation of thermal performance of aluminum finned heat exchangers and open-cell aluminum foam heat exchangers", Experimental Thermal and Fluid Science, Cilt 36, 86-92, 2012.

12. Kurtbas, I., Celik N., "Experimental investigation of forced and mixed convection heat transfer in a foam-filled horizontal rectangular channel", International Journal of Heat and Mass Transfer, Cilt 52, 1313-1325, 2009.

13. Huisseune, H., Schampheleire, S.D., Ameel, B., Michel, D. P., "Comparison of metal foam heat exchangers to a finned heat exchanger for low Reynolds number applications", International Journal of Heat and Mass Transfer, Cilt 89, 19, 2015.

14. Chen, X., Tavakkoli, F., Vafai, K., "Analysis and characterization of metal foam-filled double-pipe heat exchangers", Numerical Heat Transfer, Part A, Cilt 68, 1031-1049, 2015.

15. Schampheleirea, S.D., Jaegera, P.D., Huisseunea, H., Ameela, B., T'Joena, C., Kerpela, K.D., Paepea, M.D., "Thermal hydraulic performance of 10 PPI aluminium foam as alternative for louvered fins in an HVAC heat exchanger",
Applied Thermal Engineering, Cilt 51, No 1-2, 371-382, 2013.

16. Mancin, S., Zilio, C., Diani, A., Rossetto, L., "Experimental air heat transfer and pressure drop through copper foams", Experimental Thermal and Fluid Science, Cilt 36, 224-232, 2012.

17. Mancin, S., Zilio, C., Rossetto, L., Cavallini, A., "Foam height effects on heat transfer performance of 20 PPI aluminum foams", Applied Thermal Engineering, Cilt 49, 55-60, 2012.

18. Schampheleire, S.D., Jaeger, P.D., Kerpel, K,D., Ameel, B., Huisseune, H., Paepe, M.,D., "Experimental study of free convection in opencell aluminum foam", Procedia Materials Science, Cilt 4, 359-364, 2014.

19. Internet: Open cell metal foam, www.m-pore.de, 2014.

20. Hsieh, W.H., Wu, J.Y., Shih, W.H., ve Chiu, W.C. "Experimental investigation of heat transfer characteristics of aluminum-foam heat sink", International Journal of Heat and Mass Transfer, Cilt 47, 5149-5157, 2004.

21. Internet: Materials and Application Guide, http://www.ergaerospace.com/index.html, 2015.

22. İnternet: Flexible Isitic1, http://www.termobilim.com.tr/ termobilimkatalog.pdf, 2016.

23. Ruiz, E.C., Modelling Of Heat Transfer in open cell metal foams, Master of Science in Mechanıcal Engineering, University Of Puerto Rıco Mayagüez Campus, 2004.

24. Dukhan, N., Quinones-Ramos, P.D., Cruz-Ruiz, E., Velez-Reyes, M., Scott, E.P., "Onedimensional heat transfer analysis in open-cell 10-ppi metal foam", International Journal of Heat and Mass Transfer, Cilt 48, 5112-5120 2005.

25. Weigand, B, Analytical Methods for Heat Transfer and Fluid Flow Problems, Second Edition, Springer Heidelberg New York Dordrecht London, 2015.

26. Tzeng, S.C., Jeng, T. M., "Convective heat transfer in porous channels with 90-deg turned flow" International communications in heat and mass transfer, Cilt 49, 1452-1461, 2006.

27. Patankar, S.V., Analytical Heat Transfer and Fluid Flow, New York, 1980.

28. Sertkaya, A.A., The production of aluminum foam as heat exchanger \& heat transfer modeling, PhD thesis, Department of Mechanical Engineering, Graduate School of Natural and Applied Sciences, Selcuk University, Konya, Turkey, 2008. 